Original Paper http://ajol.info/index.php/ijbcs http://indexmedicus.afro.who.int

\title{
Characterization of moulds associated with spoilage of bread soldin Ilaro, Yewa-South, Nigeria
}

\author{
Foluso FAPARUSI ${ }^{*}$ and Adekanmi ADEWOLE
}

Science Laboratory Technology Department, Federal Polytechnic, Ilaro, Ogun State, Nigeria. *Corresponding author; E-mail: foluso.faparusi@federalpolyilaro.edu.ng

\begin{abstract}
Bread is an important staple food; however, it is highly susceptible to microbial spoilage due to postproduction contamination and improper storage. This study aimed at determining moulds associated with bread spoilage and their hydrolytic activities. Fifteen (15) brands of bread were sampled and moulds that are responsible for their spoilage were isolated using spread plate technique. The isolates were identified on the basis of colonial and microscopic characteristics. Characterization of the moulds was on the basis of their hydrolytic activities. The mould counts of the bread ranged from $1.0 \times 10^{4} \mathrm{cfu} / \mathrm{g}$ to $7.7 \times 10^{6} \mathrm{cfu} / \mathrm{g}$. The highest count was recorded in sample JB and the least count was in sample PB. The moulds associated with spoilage of the bread samples were; Aspergillus niger, Aspergillus flavus, Mucor sp., Rhizopus sp., and Penicillium sp. The predominant organism was Aspergillus niger. The moulds showed varying degrees of hydrolytic activities on milk, starch and olive oil agar media. On the basis of their hydrolytic activities, all the moulds played vital roles in the spoilage of bread. Bread, a ready-to-eat food could be a source of food-related illnesses due to moulds associated with its spoilage.
\end{abstract}

(C) 2019 International Formulae Group. All rights reserved.

Keywords: Bread, spoilage, hydrolytic activities illnesses.

\section{INTRODUCTION}

Bread is a very convenient and acceptable food. It plays important role in the diet of various age groups across the globe. Its origin dates back to the Neolithic era and is still one of the most consumed and acceptable staple food products in all parts of the world (Oluwajoba et al., 2012). The primary constituents of bread dough are flour and water. The combinations of different types and amount of flour and other ingredients, such as salts, fats, yeasts, eggs, sugars, spices, fruits, vegetables, nuts and seeds, resulted in wide varieties of bread. Bread is an important source of carbohydrates, proteins, lipids, vitamins, fibres and minerals (Saranray and Geetha, 2012).

Bread can be served in different forms at any meal of the day, eaten as a snack and is even used as an ingredient in other culinary preparations. The role of bread in man's diet is so vital; the shortage of bread is usually synonymous with hard times. Bread also plays a vital role in certain religious obligation and funerals (Savin, 2016). Bread as a staple food, its role in the life of mankind cannot be overemphasized. It will ever remain an integral part of most of the world's diet. Bread and other bakery products provide nutrients and calories for day to day activities (Khanom et al., 2016). About $50 \%$ of total calories 
required are obtained from bread in many countries (Khanom et al., 2016).

However, bread as one of the oldest prepared foods, the mode of preparation and handling in developing countries, most especially Nigeria are of great concern. Even when the bread is prepared under a standardized environment and condition, it is often prone to microbial spoilage. Although baking temperature destroys fungal spores and other microorganisms associated with bread dough, post-processing contamination is quite unavoidable, most especially in developing countries. Post-processing contamination of bread is usually through the air, baking surface, equipment, handlers and wrapping materials. Most times, bread is openly displayed on the unkept platform, even without cover or covered with cloth whose state of cleanliness cannot be ascertained. These are of public health concern. Microbial spoilage of bread like other bakery products depends on the water activity and the relative humidity of the environment. Bread stored under low relative humidity is less susceptible to microbial spoilage (Saranraj and Geetha, 2012). Microorganisms that are responsible for bread spoilage have been reported by various authors, in most cases, moulds are implicated as the dominant organisms. The major moulds of bread spoilage are species of Rhizopus, Mucor, Aspergillus, Penicillium, Eurotium, Cladosporium and Fusarium (Ogundare and Adetuyi, 2003; Ahaotu et al., 2010; Saranraj and Geetha, 2012; Unachukwu and Nwakanma, 2015). Fungal spoilage is responsible for substantial economic losses in the bakery industry; some of these fungi that are mycotoxin producers are of public health concerns (Shephard, 2008; Jard et al., 2011). Aspergillus flavus and Aspergillus parasiticus are recognised for their mycotoxins (aflatoxins) producing ability. Other organisms have also been implicated in the spoilage of bread; Bacillus subtilis is known to cause ropiness of bread (Artun et al., 2012). Most of these bread spoilage organisms are spores producers; this makes them more persistent in the food environment. However, for spoilage to occur, such food must be a source of nutrients for microbial growth, more so the organism must be able to establish itself and proliferate. The ability of an organism to utilize any available substrate lies on its ability to produce hydrolytic enzymes, required for such substrate. This study aimed at determining moulds associated with spoilage of bread and their hydrolytic abilities.

\section{MATERIALS AND METHODS \\ Collection of samples}

Fifteen (15) brands of freshly baked bread were bought from different vendors in Ilaro, Yewa-South Local Government, Ogun State, Nigeria. The vendors were sampled twice and the samples were transported in sterile polythene bags to microbiology laboratory of the Department of Science Laboratory Technology, Federal Polytechnic, Ilaro, Nigeria. The samples were kept at ambient temperature for 5-7 days in order for spoilage to set in before analyses.

\section{Isolation of moulds}

The analysis was carried out using the spread plate technique as described by Ogundare and Adetuyi (2003). The bread sample ( $1 \mathrm{~g}$ ) was homogenized in $9 \mathrm{ml}$ sterile peptone water $(0.1 \%)$ to give a stock solution. A ten-fold serial dilution was carried out and was placed on Potato dextrose agar (PDA) supplemented with $50 \mathrm{mg}$ streptomycin per lire. The inoculum $(0.1 \mathrm{ml})$ was spread on the medium using sterile bent glass rod. The plates were incubated at a temperature of $27 \pm$ $2^{\circ} \mathrm{C}$ for 3 to $5 \mathrm{~d}$. The chosen dilutions were plated out in triplicate. The colony forming unit per gram (cfu/g) was enumerated accordingly. The isolates were subcultured on the same medium (PDA) to obtain pure cultures. Pure isolates were preserved on agar slants and stored in the refrigerator pending further analyses.

\section{Identification of isolates}

The isolates were identified using the conventional morphological technique. The isolates colonial and microscopic characteristics were used as the basis for the identification. The nature of the mycelia and the reverse colour of freshly sub-cultured isolate $(72 \mathrm{~h})$ were observed. Microscopic examination of the isolates was carried out after the mycelia were stained with 
lactophenol cotton-blue. The isolate mycelia were spread on clean grease free glass slide and teased with inoculating needles followed by addition of two (2) drops of lactophenol cotton-blue and placed a coverslip on it. Microscopic characteristics such as colonial heads, stipe colour and length, vesicle shape and serration, colonial shape and colour were observed under a compound microscope. Fungal taxonomic descriptions and identification keys were used as references (Adeniran and Abiose, 2009; John and Mishra, 2017).

\section{Determination of hydrolytic activities of the isolates}

Screening for the amylolytic activity of the isolated moulds was carried out using Starch agar. The modified starch agar medium of Balkan and Ertan (2005) containing $\mathrm{Na}_{2} \mathrm{HPO}_{4} ; 1.46 \mathrm{~g}, \mathrm{NH}_{4} \mathrm{NO}_{3} ; 1.0 \mathrm{~g}, \mathrm{KCl} ; 0.5 \mathrm{~g}$, $\mathrm{MgSO}_{4} .7 \mathrm{H}_{2} 0 ; 0.1 \mathrm{~g}, \mathrm{FeSO}_{4} .7 \mathrm{H}_{2} \mathrm{O} ; 0.01 \mathrm{~g}$, soluble starch; 20.0g, agar; $20.0 \mathrm{~g}$ and supplemented with chloramphenicol in 1Litre of distilled water, was used for the analysis. Mould disc $(7 \mathrm{~mm})$ from the previous plate was centrally inoculated on the starch agar plate. The plates were incubated at $27 \pm 2{ }^{\circ} \mathrm{C}$ for $4 \mathrm{~d}$. After incubation, the plates were flooded with Iodine solution (Iodine- $0.2 \mathrm{~g}$, potassium iodide- $0.4 \mathrm{~g}$, distilled water- 100 $\mathrm{ml}$ ), and were observed for the diameter of a clear zone around the colony. The clear zone depicts starchy hydrolysis; amylolytic activity (Mukunda et al., 2012).

Casein agar medium was prepared by dissolving $1 \mathrm{~g}$ casein and $2 \mathrm{~g}$ agar in $100 \mathrm{ml}$ distilled water. The medium was sterilized using autoclave at $121^{\circ} \mathrm{C}$ for $15 \mathrm{~min}$. Under the aseptic condition, the medium, approximately $20 \mathrm{ml}$, was poured into each sterile Petri-dish and allowed to solidify at room temperature. The isolates were directly placed on the plates and were incubated at a temperature of $30 \pm 2$ ${ }^{\circ} \mathrm{C}$ for $7 \mathrm{~d}$. After incubation, the formation of a zone of casein clearance was determined by visual observation (Sumantha et al., 2005).

The lipolytic activity of the mould isolates was determined using modified method of Kotula et al. (1982). The moulds were tested for their ability to produce lipase by direct plating on Olive oil agar (1\% peptone, $0.5 \% \mathrm{NaCl}, 0.2 \% \mathrm{CaCL}_{2}, 2 \%$ agar and $4.7 \mathrm{ml}$ of Olive oil per litre). Olive oil was used in place of Tween 80 . The plates were point inoculated at the centre and were incubated at $28 \pm 2{ }^{\circ} \mathrm{C}$ for 3-7 d. Lipolytic activity of the isolates was determined on the basis diameter of a clear zone around the colony.

Proteolytic, amylolytic and lipolytic activities of the isolates were determined on the basis of the diameter of clear zones around the colonies, which was measured in $\mathrm{mm}$ and recorded accordingly.

\section{RESULTS}

The bread samples showed high mould counts that ranged from $1.0 \times 10^{4} \mathrm{cfu} / \mathrm{g}$ to 7.7 x $10^{6} \mathrm{cfu} / \mathrm{g}$ (Table 1), after five (5) days of storage. All the bread samples showed signs of spoilage after five (5) days (Result not shown). Sample PL had the least mould load $\left(1.0 \times 10^{4} \mathrm{cfu} / \mathrm{g}\right)$ while the highest count $(7.7$ x $10^{6} \mathrm{cfu} / \mathrm{g}$ ) was recorded in sample JS. All the bread samples showed the presence of moulds. On the basis of colonial and microscopic characteristics, a total of four (4) fungal genera, comprising Mucor, Rhizopus, Penicillium and Aspergillus were isolated from the bread samples (Table 2). The cultural and microscopic characteristics of the isolates were as shown in Table 2. Only Aspergillus was identified to species level as Aspergillus niger and Aspergillus flavus (Table 2). The moulds associated with various bread samples are shown in Table 3. Aspergillus species were the dominant organisms. The presence of Aspergillus was noticed in ten (10) bread samples. Samples AJ, MY, 14B and OO showed the presence of a single organism (Table 3). Hydrolytic activities of the isolates were as shown in Table 4. All the isolates showed varying degrees of hydrolytic activities. Aspergillus niger recorded the highest visible halos of $16 \mathrm{~mm}$ and $18 \mathrm{~mm}$ on starch agar and milk agar respectively. The highest hydrolytic activity $(21 \mathrm{~mm})$ on olive oil agar was showed by Rhizopus sp. Penicillium sp. had the least hydrolytic on the three media. 
Table 1: Mould loads of the bread samples.

\begin{tabular}{llc}
\hline S/N & Samples & Average mould count $(\mathbf{c f u} / \mathbf{g})$ \\
\hline 1 & JS & $7.7 \times 10^{6}$ \\
2 & AJ & $4.6 \times 10^{5}$ \\
3 & TM & $1.7 \times 10^{5}$ \\
4 & TD & $5.6 \times 10^{5}$ \\
5 & PL & $1.0 \times 10^{4}$ \\
6 & IB & $1.0 \times 10^{5}$ \\
7 & MY & $1.6 \times 10^{6}$ \\
8 & AO & $1.0 \times 10^{5}$ \\
9 & OF & $1.0 \times 10^{5}$ \\
10 & 14B & $5.5 \times 10^{5}$ \\
11 & ST & $1.0 \times 10^{5}$ \\
12 & OO & $1.0 \times 10^{6}$ \\
13 & SC & $5.6 \times 10^{5}$ \\
14 & FP & $1.3 \times 10^{5}$ \\
15 & IO & $2.0 \times 10^{5}$ \\
\hline
\end{tabular}

Table 2: Morphological characteristics of the isolates.

\begin{tabular}{|c|c|c|}
\hline Colonial characteristics & Microscopic characteristics & Probable isolates \\
\hline $\begin{array}{l}\text { A densely packed conidia } \\
\text { reverse of the plant is } \\
\text { florescent yellow }\end{array}$ & $\begin{array}{l}\text { Yellowish brown smooth conidosphore, } \\
\text { rough globose conidiospores, biseriate, } \\
\text { phialides. }\end{array}$ & Aspergillus niger \\
\hline $\begin{array}{l}\text { Fast growing, cream } \\
\text { white/large fluffy white } \\
\text { colonies almost covering the } \\
\text { whole plate }\end{array}$ & $\begin{array}{l}\text { The sporangiophore emerges singly, } \\
\text { directly from the hypha without stolon } \\
\text { and rhizoids; sporangiophore emerges } \\
\text { from any part of the mycelia, not septate } \\
\text { hyphae. }\end{array}$ & Mucor sp. \\
\hline Pale bluish green to dark green & $\begin{array}{l}\text { Spherical, smooth green conidia with } \\
\text { branched septate hyphae, conidiophores } \\
\text { are branched with chains of conidia that } \\
\text { look like a brush. }\end{array}$ & Penicillium sp. \\
\hline $\begin{array}{l}\text { Light grey-green to pale, blue- } \\
\text { green, fluffy mycelium cream } \\
\text { white to dull white, reverse of } \\
\text { the plates yellow-orange and } \\
\text { wrinkled }\end{array}$ & $\begin{array}{l}\text { Pale brown conidiosphore, globose, } \\
\text { smooth and rough conidiospores, } \\
\text { biseriate and uniseriate }\end{array}$ & Aspergillus flavus \\
\hline $\begin{array}{l}\text { Fast growing, large fluffy } \\
\text { white milky colonies; cottony } \\
\text { mycelia which later turns } \\
\text { black as culture gets old }\end{array}$ & $\begin{array}{l}\text { Aseptate hyphae with uptight } \\
\text { sporangiophore connected by stolon and } \\
\text { rhizoids, sporangiophore develops in } \\
\text { clusters above the nodes, dark pear- } \\
\text { shaped sporangium on hemispherical } \\
\text { columella bears sporangiospores }\end{array}$ & Rhizopus sp. \\
\hline
\end{tabular}


Table 3: Moulds associated with the bread samples.

\begin{tabular}{|c|c|}
\hline Samples & Associated organisms \\
\hline JS & Aspergillus niger, Mucor sp. \\
\hline AJ & Aspergillus niger \\
\hline TM & Rhizopus sp., Aspergillus niger. \\
\hline TD & Rhizopus sp., Mucor sp. \\
\hline PL & Mucor sp., Rhizopus sp. \\
\hline IB & Rhizopus sp., Penicillium sp. \\
\hline MY & Aspergillus flavus \\
\hline $\mathrm{AO}$ & Penicillium sp., Rhizopus sp. \\
\hline $\mathrm{OF}$ & Penicillium sp., Rhizopus sp. \\
\hline 14B & Aspergillus niger. \\
\hline ST & Aspergillus niger, Penicillium sp. \\
\hline $\mathrm{OO}$ & Aspergillus flavus \\
\hline $\mathrm{SC}$ & Aspergillus niger, Penicillium sp. \\
\hline FP & Aspergillus niger, Rhizopus sp. \\
\hline IO & Aspergillus flavus, Mucor sp. \\
\hline
\end{tabular}

Table 4: Hydrolytic activities of the isolates.

\begin{tabular}{lccc}
\hline \multirow{2}{*}{ Isolates } & \multicolumn{3}{c}{ The average diameter of zones of clearance (mm) } \\
\cline { 2 - 4 } & Starch agar & Milk agar & Olive oil agar \\
\hline Aspergillus niger & 16 & 18 & 15 \\
Aspergillus flavus & 10 & 9 & 13 \\
Penicillium sp. & 8 & 8 & 12 \\
Mucor sp. & 12 & 15 & 17 \\
Rhizopus/sp. & 10 & 13 & 21 \\
\hline
\end{tabular}

\section{DISCUSSION}

Bread, as a perishable staple, ready-toeat food usually undergoes deterioration during storage due to microbial activities. The ability of microorganisms to establish themselves on any substrate is a product of availability of needed nutrients on such food. Bread is known to be rich in starch, protein and fat, the proximate composition of the bread might determine the type of microorganism that grows on it and brings about deterioration in quality. All the bread samples showed signs of spoilage like black and light green coloration, unpleasant odor and repulsive appearance, after storage at ambient temperature $\left(28 \pm 2^{\circ} \mathrm{C}\right)$ for five days (Ogunsakin et al., 2015). The bread samples were stored at this temperature because it is the usual temperature adopted for keeping bread by most homes in Nigeria. The incessant power supply in the country might have discouraged people from keeping bread at refrigerated temperature.

All the bread samples showed a high mould count, greater than the standard threshold fungi count of $10^{4}$ in food (Amadi et al., 2014). On the basis of the moulding load, the samples are not suitable for human consumption. The high microbial load might be due to post-production contamination from the personnel, manufacturing environment, poor transportation system or packaging materials. The production environment is usually full of air-born fungi which eventually contaminate the bread during cooling, slicing and wrapping. Moreover, the bread is usually 
packed by personnels with bare hands that most times not washed. The high fungal count was in agreement with the findings of Ogundare and Adetuyi (2003).This finding also agreed with the work of Oluwalana et al. (2012) that reported high fungal count $\left(7.0 \times 10^{4} \mathrm{sfu} / \mathrm{g}\right)$ in sweet potato wheat composite bread. The similarity of the findings might be due to similar processing and handling techniques.

The five (5) moulds; Mucor sp., Aspergillus niger, Aspergillus flavus, Penicillium sp. and Rhizopus sp. that were responsible for the spoilage of the bread samples had earlier been reported by other authors in bread spoilage (Ogundare and Adetuyi, 2003; Ahaotu et al., 2010; Unachukwu and Uwakanma, 2015). Fungi are contaminants of foods due to continuous presence of their spores as air propergules. Uzeh et al. (2012) reported the presence of Aspergillus niger, Aspergillus fumigatus, Penicillium sp. and other fungal contaminants in roasted meat product (tsire-suya). Rhizopus and Mucor are known as bread moulds. The presence of these organisms in bread could be due to the presence of their spores in raw material (flour) used for production and resistance of the spores to heat treatment during baking. High fungal count $\left(4 \times 10^{4}\right.$ $\mathrm{sfu} / \mathrm{g}$ ) has been reported by Oluwalana et al. (2012) in sweet potato wheat flour for bread making. This could also be due to postproduction contamination from the production environment and during transportation. Some of these organisms could be mycotoxin producing strains that can pose serious health challenges to the consumers (Shephard, 2008; Ezekiel et al., 2012). Strains of Aspergillus species and Penicillium species isolated from food and feeds have been reported for their toxigenic potentials (Hathout and Aly, 2014). These organisms could cause a great economic loss in the bakery industry. The predominant organism was Aspergillus niger. This could be due to the ability of the organism to utilize the bread constituents for growth. The dominance of Aspergillus niger was in contrary to the works of Unachukwu and Uwakanma (2015) that reported Rhizopus as the dominant organisms, this variation might be due to the quality of raw materials, production environment, packaging materials and personal hygiene. This work was in agreement with the findings of Hassan et al. (2014) that worked on similar materials.

The isolates showed varying degrees of hydrolytic activities. This was in agreement with the findings of Ahaotu et al. (2010). The hydrolytic activity might be due to the ability of organisms to utilize the substrates for their growth. High hydrolytic activity by Aspergillus niger on starch agar and milk agar shows the ability of the organisms to utilize the substrate for growth as a result of the production of required enzymes (amylase and protease) for hydrolysis of starch and protein. The high hydrolytic activity of Rhizopus species on olive oil agar might be due to extracellular protease secreted.

\section{Conclusion}

Moulds that are associated with bread spoilage were determined and their hydrolytic activities were investigated. Bread is prone to fungal spoilage. Four mould genera were found associated with spoilage of the bread samples. They all showed varying degrees of hydrolytic activities. Moreover, if proper preservative measures are not taken, the moulds can bring enormous economic losses to bakery industry. Bread could be a source of health-related issues due to the toxigenic ability of some of the fungal isolates.

\section{COMPETING INTERESTS}

The authors of the paper declare that there is no competing interest.

\section{AUTHORS' CONTRIBUTIONS}

FF designed the study and collected the samples. FF and AA conducted the experimental works, drafted the manuscript, 
revised and approved the copy of the manuscript.

\section{ACKNOWLEDGEMENTS}

The authors appreciate the Department of Science Laboratory Technology, Federal Polytechnic, Ilaro for the provision of Laboratory space for the study.

\section{REFERENCES}

Adeniran AH, Abiose SH. 2009. Amylolytic potentiality of fungi isolated from Nigerian agricultural waste. Afr. J. of Biotech., 8(4): 667-672.

Ahaota NN, Ogueke CC, Ahaota I. 2010. Hydrolytic enzymes of moulds involved in bread spoilage. New York Sc. J., 3(11): 27-36.

Amadi JE, Onyejekwe PC, Ozokonkwo CO, Adebola MO. 2014. Isolation and identification of moulds associated with four selected snacks sold in Nnamdi Azikiwe University, Awka and its environs. Appl. Sc. Reports, 7(1): 32-35.

Artun Y, Figen C, Gul ES. 2012. Detection of rope-producing Bacillus in bread and identification of isolates to species level by Vitek 2 System. J. Biol. Environ. Sc., 6(18): 243-248.

Balkan B, Ertan F. 2005. Production and Properties of $\alpha$-amylase from Penicillium chrysogenum and its Application in Starch Hydrolysis. Prep. Biochem. Biotech., 40: 213-228. DOI: https://dx.doi.org/10.1081/PB200054740

Ezekiel CN, Bandyopadhyay R, Sulyok M, Warth B, Krska R. 2012. Fungal and bacterial metabolites in commercial poultry feed from Nigeria. F. Add. Contaminants, 29(8): 1822-1299. DOI: https://dx.doi.org/10.1080/19440049.201 2.688878

Hathout SA, Aly SE. 2014. Biological detoxification of mycotoxins: a review. Annals of Microbiology, 64: 905-919.
DOI: https://dx.doi.org/10.1007/s13213014-0899-7.

Hassan N, Farideh T, Seyed AM, Mohebbat M. 2014. Isolation, identification and growth's composition of mould types in a cake factory environment and final products. Inter. J. Adv. Biol. Biomed. Res., 2(8): 2505-2517.

Jard G, Liboz T, Mathieu F, Guyonvarc'h A, Lebrihi A. 2011. Review of mycotoxin reduction in food and feed: from prevention in the field to detoxification by adsorption or transformation. $F$. Additive and Contaminants, part A, 28: 1590-1609. DOI: https://dx.doi.org/10.1080/19440049.201 1.595377

John A, Mishra S. 2017. A Study on bread mould spoilage by using lactic acid bacteria and yeast with antifungal properties. Inter. J. Food Sc. Nutri., 2(4): 192-195.

Khanom A, Shammi T, Kabir MS. 2016. Determination of microbiological quality of packed and unpacked bread. Stamford J. Microbiol., 6(1): 24-29. DOI: https://dx.doi.org/10.3329/sjm.v6i1.3351 5.

Kotula AW, Compano SG, Kinsma SM. 1982. Proteolytic and lipolytic activity of moulds isolated from Aged Beef. $J$. Food Prot., 45(13): 1242-1244.

Mukunda S, Onkarappa R, Prashith-Kekuda TR. 2012. Isolation and Screening of Industrially important fungi from the Soils of Western Ghats of Agumbe and Koppa, Karnataka, India. Sc., Technol. Arts Res. J., 1(4): 27-32. DOI: https://dx.doi.org/10.4314/star.v1i4.9881 6.

Ogundare AO, Adetuyi FC. 2003. Studies on the microbial population of bread baked with wheat flour from southwestern Nigeria. Food, Agricult. Environ., 1(3\&4): 85-87. https://dx.doi.org/10.1234/4.2003.410. 
Ogunsakin OA, Banwo K, Ogunremi OR, Sanni AI. 2015. Microbiological and physicochemical properties of sourdough bread from sorghum flour. Inter. Food Res. J., 22(6): 2610-2618.

Oluwajoba SO, Malomo O, Ogunmoyela OAB, Dudu OEO, Odeyemi A. 2012. Microbiological and nutritional quality of warankashi enriched bread. $J$. Microbiol., Biotech. Food Sc., 2(1): 4268.

Oluwalana IO, Malomo SA, Ogbodogbo EO. 2012. Quality assessment of flour and bread from sweet potato wheat composite flour blends. Int. J. Bio. Chem. Sci., 6(1): 65-76. DOI: https://dx.doi.org/10.4314/ijbcs.v6i1.6.

Saranraj P, Geetha M. 2012. Microbial Spoilage of Bakery Products and its control by Preservatives. Inter. J. Pharm. Biol. Archives, 3(1): 38-48.

Savin P. 2012. Bread: From culture to phraseological imaginary. Philological Jassyensia, Anul VIII, Nr., 2(16): 185191.
Shephard GS. 2008. Impact of mycotoxin in human health in developing countries. $F$. Add. Contaminants, 25(2): 146-151. DOI: https://dx.doi.org/10.1080/02652030701 567442.

Sumantha A, Sandhya C, Szakacs G, Soccol CR, Pandey A. 2005. Production and partial purification of a natural metalloprotease by fungal mixed substrate fermentation. Food Tech. Biotech., 43(4): 313-309.

Unachukwu MN, Nwakanma C. 2015. Fungi associated with spoilage of bread in Enugu State. Inter. J. Curr. Microbiol. Appl. Sc., 4(1): 989-995.

Uzeh RE, Akinyemi MO, Nduaguba CC. 2012. Microbiological and physicchemical characteristics of stored tsiresuga, a roasted meat product. Int. J. Biol. Chem. Sci., 6(4): 1804-1809. DOI: https://dx.doi.org/10.4314/ijbcs.v6i4.35. 